Int. J. Dev. Biol. 52: 195-199 (2008)

doi: $10.1387 /$ ijdb.072328js

\title{
Genetic control of gamete quality in the mouse - a tribute to Halina Krzanowska
}

\author{
JOZEFA STYRNA* \\ Department of Genetics and Evolution, Institute of Zoology, Jagiellonian University, Krakow, Poland
}

\begin{abstract}
In this article, we summarise the principal research findings of the distinguished Polish scientist, Professor Halina Krzanowska, related to the genetic control of mammalian gamete quality. During the early stages of her career, Halina Krzanowska conducted experiments on poultry and then she moved on to work on mice. All her research on gamete quality was conducted on the research models, consomic, congenic and recombinant inbred strains, which Krzanowska developed herself. These models differed mostly in their fertility. Krzanowska was one of the first researchers to demonstrate the influence of chromosome $Y$ on the morphology of mice spermatozoa. She also showed that the uterotubal junction is in vivo a selection barrier for the morphologically abnormal spermatozoa, whereas in vitro abnormal spermatozoa are able to participate in fertilization, the function of selective barrier being performed by the granulosa cell layer and the zona pellucida. Another model which Krzanowska produced were chimaeras, which she used to find out if the percentage of abnormal spermatozoa and the efficiency of fertilization are determined by germ cells themselves or by environmental factors and she discovered that sperm head shape, the proportion of abnormal sperm and fertilizing capacity are determined mainly by the genotype of germ cells and only minimally by environmental factors.
\end{abstract}

KEY WORDS: mouse, sperm quality

On $3^{\text {rd }}$ June 2005 the Committee of Embryology and Morphology at the Polish Academy of Arts and Sciences, Department of Genetics and Evolution Jagiellonian University and Polish Academy of Sciences held a memorial session devoted to the work of one of the most distinguished Polish geneticists, Professor Halina Krzanowska (1926 - 2004) (Fig. 1).

Her professional career started in 1948 in the Department of Comparative Anatomy led by Professor Zygmunt Grodzinski. In 1952 she moved to the Department of Experimental Biology of the Institute of Animal Reproduction in Pulawy, where she worked as a research associate under the supervision of Professor Laura Kaufman, and later as the director of this department. During 1957 she stayed at a well-known Poultry Research Centre in Edinburgh, Scotland, as a fellow of the Rockefeller Foundation. In 1964 she returned from Pulawy to Krakow to chair the Department of Genetics and Evolution, a position which she held for the next 32 years.

The history of the Department of Genetic and Evolution began in 1953, when Professor Teodor Marchlewski, then Rector of the Jagiellonian University, created the Chair of Evolution with the Department of Evolution within the Faculty of Biology and Earth
Sciences. Four years later, the Ministry of a Higher Education carved out the Section of Breeding Biology from the Institute of Zootechniques and after a reorganization, moved the section to the Chair of the Evolution (later renamed the Department of Genetics and Evolution) at the Jagiellonian University.

At the beginning, the research of the Department had been focused mainly on the possibility of inheriting phenocopies i.e. phenotypic changes resulting from the environmental factors. Head of the Department, Professor Marchlewski, devoted the final years of his career to the study of the psychological features of mammals, especially hunting dogs and horses. Professor Marchlewski's research on phenocopies was continued by other researchers, - including Dr Borzedowska (Borzedowska, 1963; Borzedowska, 1966), who published several papers on the genetic analysis on Drosophila melonogaster with the preserved phenocopies. After the premature death of Professor Marchlewski, the Minister of a Higher Education nominated Halina Krzanowska, alumnus and associate professor of the Jagiellonian University, as a head of the Department. Since 1964 the genetic program of the Department was expanded to include research on the phenomena of heterosis. In the course of this research it was

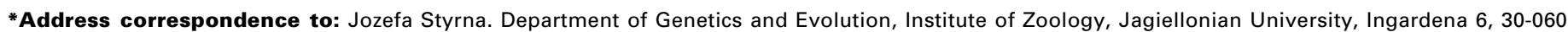
Krakow, Poland. Fax: +48-012-634-2716. e-mail: styr@zuk.iz.uj.edu.pl
}

Published online: 14 February 2008

$0214-6282 / 2008 / \$ 35.00$

(C) UBC Press

Printed in Spain 


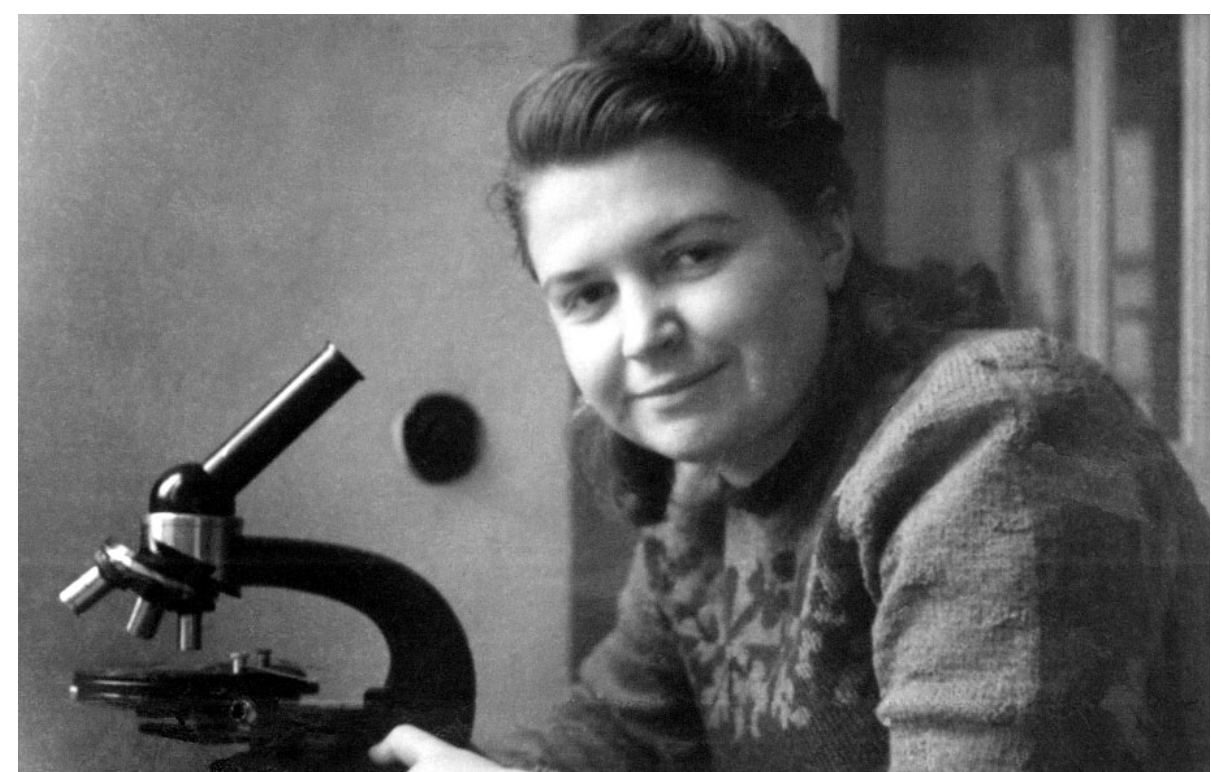

Fig. 1. Halina Krzanowska in the laboratory of the Department of Comparative Anatomy (1950).

discovered that the inbred strains of laboratory mice show very specific fertility disorders. These strains had been used by the Department of Genetics and Evolution as the natural models for the genetic analysis of fertility factors.

Besides earlier work on poultry (Krzanowska, 1948; Krzanowska, 1949; Krzanowska, 1954; Krzanowska, 1956; Krzanowska, 1959), mainly in Pulawy, Professor Krzanowska's research involved laboratory mice with focus on the genetic quality of gametes, an area which she pioneered and developed in Poland.

Krzanowska's first animal models in the research on gamete quality were two inbred strains: KE and KP. She developed these strains from an original heterozygous population, from which also an outbred control stock was derived. The inbred strain KE with very low fertility rates turned out to be particularly useful. When KE males were used for mating, nearly $30 \%$ of ova remained unfertilized. Such inefficiency of KE males was mostly caused by a high incidence of morphologically abnormal spermatozoa with deformed heads. Krzanowska described four basic classes of abnormal sperm: 1) almost normal head, with slightly bent acrosome (type 1b) or head with changed curvature in the distal part (type 1a); 2) narrow, condensed heads often containing a longitudinal canal of very low stainability; 3) misshapen heads distended mainly in the apical or distal part; 4) severely misshapen heads, some with vacuoles or canals (Fig. 2) (Krzanowska, 1962; Krzanowska, 1976; Buda and Krzanowska, 1978).

These abnormalities in spermatozoa and the mode of their inheritance were studied in detail. For this purpose the backcrosses and F2 generations were bred from $\mathrm{F} 1$ of $\mathrm{KE}(16 \%$ of sperm abnormalities) and CBA/Kw hybrids (in CBA/Kw only $6 \%$ of abnormal sperm was detected). There was an obvious segregation of genotypes, and the preliminary calculation based on the number of phenotypes suggested that this trait is polygenically determined, and at least three genes are involved, one of them being located on chromosome $Y$. This conclusion was drawn from the difference between the reciprocal crosses, which cannot be ascribed to cytoplasm, nor to chromosome $X$ (Krzanowska, 1966; Krzanowska 1967; Krzanowska, 1972b).

For many years the $Y$ chromosome was believed to be rather genetically empty, functioning only in male sex determination and in providing a pairing partner for the $\mathrm{X}$ chromosome. Experiments performed in the Department of Genetics and Evolution of the Jagiellonian University conducted by Krzanowska and her coworkers on inbred strains of mice, which differed in the level of sperm abnormalities and efficiency of fertilization, showed that the source of the $Y$ chromosome plays a significant role in the inheritance of these traits and possibly contains genes controlling the course of spermatogenesis (Krzanowska, 1969; Krzanowska, 1972b; Krzanowska, 1986). This was confirmed later by the finding of an increased level of sperm abnormalities in males with a partial deletion of the $Y$ chromosome (Styrna et al., 1991).

These studies were the first ever description of the role of $Y$ chromosome in determination of abnormal sperm heads. The linkage of the factor affecting male fertility with the $Y$ chromosome may be important from the evolutionary point of view. Such a gene (or genes) is restricted to males only, where it has high selective value and where it is exposed to strong selection (Krzanowska, 1969; Krzanowska, 1972b).

As it was mentioned above, studies on the lower fertility of inbred strains of mice revealed that KE strain had more than $30 \%$ of unfertilized ova. Half of them contained one or more spermatozoa within the perivitelline space. Subsequent studies showed that the highest incidence of supplementary spermatozoa in the eggs, was found in the matings involving the strains with the highest percentage of morphologically abnormal spermatozoa: $\mathrm{KE}$ and $\mathrm{C} 57 \mathrm{BL}, 16$ and $21 \%$ respectively, whereas the lowest incidence involved the $\mathrm{CBA} / \mathrm{Kw}$ strain with only $6 \%$ of abnormal spermatozoa. The conclusion, first reached by Braden (1958), that the male strain is important in establishing the proportion of the ova penetrated by more that one spermatozoon was confirmed in Professor Krzanowska's experiments, but the importance of the female strain was more clearly evident in Krzanowska's, than in Braden's experiments. Professor Krzanowska suggested that the acrosome of the spermatozoon and the cortical granules of the egg, may have been involved in the process of sperm entry into the ovum. It was thus, not unreasonable to think that the same genes which influenced some abnormality of sperm function may also have been involved in anomalies of the cortical granules, their number or reaction (Krzanowska, 1969; Krzanowska, 1970).

In addition, irregularity of the oestrous cycle and the low libido of both sexes were the significant contributors to the poor mating frequency of KE mice (Krzanowska and Musialek, 1971).

No relationship was found between the age of the mature males and fertilization rate in fertile copulations. In the young males a large proportion of abnormal spermatozoa were found, but these were eliminated before the animal reached maturity. The abnormal spermatozoa of mature males did not pass through 
the uterotubal junction and consequently did not reach the site of fertilization. Only when the proportion of abnormal spermatozoa was extremely high (above 50\%), fertilization rate dropped and copulations were completely sterile (Krzanowska, 1974).

Before entering the vitellus, the fertilizing spermatozoon has to pass through two barriers, the cumulus oophorus and the zona pellucida. This is accomplished through the action of hyaluronidase, which disperses the granulosa cells, and proteolytic enzymes, which dissolve the zona pellucida. It is likely that spermatozoa from different strains differ in quantities of these enzymes, and/or the resistance of the cell layers surrounding the egg to the action of the enzymes is different. The experiments performed on mice belonging to an outbred strain and four inbred strains: $\mathrm{C} 57 \mathrm{BL}, \mathrm{CBA} / \mathrm{Kw}, \mathrm{KP}$ and $\mathrm{KE}$, showed that the resistance of the cell layers surrounding the eggs to the action of enzymes, depended on the physiological state of the egg. Lysis of the zona by pronase and trypsin was most rapid in fresh, unfertilized eggs. Ageing rendered the zona more resistant to the action of enzymes, an effect which was most evident in old fragmented ova. The most important result of Krzanowska's studies was the finding that both the granulosa cell layer and the zona pellucida of inbred strains differed in their resistance to the action of enzymes. The zona was found to be most resistant and the effectiveness of the zona reaction less efficient in the ova of KE strain (Krzanowska, 1972a).

As it was mentioned above, the fertilized eggs of the KE and C57BL strains had high incidence of supplementary spermatozoa found in the perivitelline space. The fertilization rate of the KE eggs was low, $30 \%$ of the eggs remaining unfertilized and about half of them containing spermatozoa in the perivitelline space. By contrast, all the available $\mathrm{CBA} / \mathrm{Kw}$ ova were fertilized and the incidence of supplementary spermatozoa was very low. Supplementary spermatozoa may have been prevented from entering the ova by the very tight layer of granulosa cells surrounding eggs of $\mathrm{CBA} / \mathrm{Kw}$ strain, which was more resistant to the action of hyaluronidase than in the other strains. Moreover the zona reaction after fertilization seemed to be very effective as judged by the difference, between the fertilized and unfertilized eggs, in their resistance to the action of proteolytic enzymes. In the KE strain the zona pellucida of the unfertilized eggs was so resistant to the action of proteolytic enzymes that it did not differ from that in fertilized eggs of the C57BL strain. The relatively slow process of sperm entry through the zona in this strain seemed to favor the simultaneous penetration of more than one spermatozoon, since, in addition, the effectiveness of the zona reaction was extremely low. As the block in the zona developed after attachment of the spermatozoon to the vitellus, it was likely that this latter process may have been impaired in KE strain eggs, which would also explain the lower fertilization rate (Krzanowska, 1972a).

Three groups of eggs: intact, cumulus free and zona-free were inseminated in vitrowith spermatozoa from C57BL male mice and incubated for 1-2 h. In fixed, toluidine blue-stained preparations, spermatozoa surrounding the eggs or attached to them remained colorless, while sperm heads that had penetrated the vitellus were strongly stained. These spermatozoa, whose chromatin was still condensed, were used to evaluate the head shapes. The proportion of abnormal sperm heads of all classes was significantly lower in intact than in cumulus and zona-free eggs, and severely abnormal forms were not found in intact eggs. These results suggested that abnormal spermatozoa were able to participate in fertilization, although their chances of penetrating the ova in vitro were greatly reduced in the presence of egg investments, especially of the cumulus (Krzanowska and Lorenc, 1983).

In the 1970s, the fertility factors were believed to be polygenically determined, which made the analysis difficult. Several genes causing significant defects of spermatozoa were already known, some of them being certainly autosomal (Beatty, 1970; Bartke and Krzanowska, 1972). One of the best methods to separate the Y-linked factor from the other polygenes and to prove its role in the production of morphologically as well as physiologically abnormal spermatozoa was the development of the congenic strains differing in the origin of the Y-chromosome (Krzanowska, 1989). After seven generations of backcrosses performed by Krzanowska, to introduce the $\mathrm{Y}$ chromosome from CBA/Kw $(6 \%$ of abnormal spermatozoa) to genetic background of the KE strain $(16 \%$ of sperm abnormalities), the total percentage of abnormalities was significantly reduced. She concluded that the $Y$ chromosome played an important role in determining the total percentage of sperm head abnormalities, but was not involved in influencing specific abnormality types (Krzanowska, 1976; Krzanowska, 1978; Krzanowska, 1989).

The first wave of spermatogenesis in pubertal mice is highly inefficient. In seminiferous tubules of 10-20 day-old males, many spermatocytes and spermatids degenerate, especially at the forefront of the spermatogenic line, and in the first ejaculates most spermatozoa are abnormal, several with missing or severely misshapen heads (Krzanowska, 1981). As in some subfertile men and mice, the death of spermatogenic cells and formation of inviable gametes had been correlated with $X-Y$ chromosome dissociation at meiosis (Burgoyne,_1979). Burgoyne and Baker (1984) put forward a hypothesis of a general meiotic quality control mechanism, which eliminated all gametocytes in which any chromosome pair failed conjugation. In Krzanowska's studies first meiotic metaphases were studied in adult and pubertal males

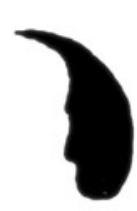

normal

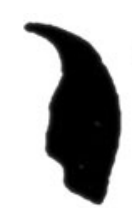

la

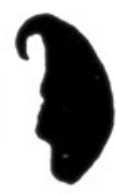

$1 \mathrm{~b}$

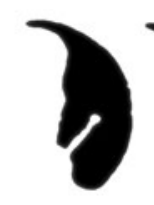

$2 \mathrm{a}$

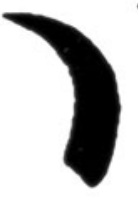

$2 \mathrm{~b}$

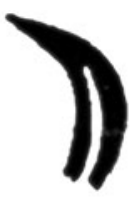

$2 \mathrm{c}$

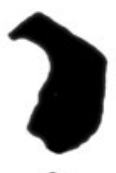

$3 \mathrm{a}$

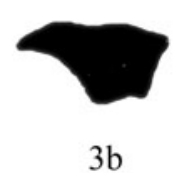

$3 b$

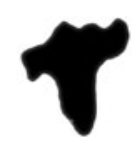

$4 \mathrm{a}$

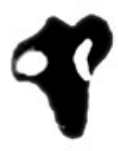

$4 \mathrm{~b}$
Fig. 2. Typical examples of sperm head abnormalities (according to Buda and Krzanowska, 1978). Four classes of abnormal spermatozoa heads were distinguished by Krzanowska on the basis of microscopic observation of sperm in adult male mice. These are Type 1 (almost normally developed head with slightly distorted acrosome (Type 1b), head with slightly changed distal part (Type 1a); Type 2 (basicly narrow head, frequently contains canal with low stainability and Type 3 (considerably misshapen head, mainly in the apical or distal partseriously misshapen head, some of them possessing vacuoles or canals with low stainability). 
from inbred strains differing in testis size, efficiency of spermatogenesis, proportion of abnormal sperm heads, and fertilizing capacity of spermatozoa, in order to test whether there was any correlation between these characteristics and the level of chromosome univalency. The comparison of KE and KE.CBA (with $Y$ chromosome from KE strain) congenic strains showed that the low level of $X-Y$ univalency typical for the KE strain did not change by introduction of the $Y$ chromosome from the CBA strain, characterized by a high level of univalency. This supported the results of Imai et al., (1981) that the genes responsible for sex chromosome dissociation were not located on the $Y$ chromosome (Krzanowska, 1989). In addition, it was also shown (Polanski and Krzanowska, 1991) that the frequency of X-Y dissociation did not correlate with aneuploidy of sperm chromosomes.

Aggregation chimaeras from $\mathrm{KE}$ and $\mathrm{CBA} / \mathrm{Kw}$ mice were produced to investigate whether the differences in percentage of abnormal heads and efficiency of fertilization were intrinsic or extrinsic to spermatogenic cells. Among 24 chimaeras, 5 were germ-line chimaeras. All of them produced about $98 \% \mathrm{KE}$ and only $2 \% \mathrm{CBA} / \mathrm{Kw}$ spermatozoa, which indicated strong selection against $\mathrm{CBA} / \mathrm{Kw}$ germ cells. On the other hand, mature CBA/Kw spermatozoa showed high competitive ability, because the proportion of agouti progeny (from the CBA/Kw component) sired by those males was significantly higher than the proportion of CBA/ Kw spermatozoa,- as estimated after every mating from vaginal plug preparations. This indicated that sperm head shape, the level of sperm abnormalities and fertilizing capacity were determined mainly autonomously by genes acting in the germ cells. The internal environment created by foreign somatic cells caused only minor modifications (Krzanowska et al., 1991).

Research on the mutants with an extensive deletion on the $Y$ chromosome, a strain imported by Krzanowska's assistant from National Institute of Genetics, Mishima, Japan in 1980s, confirmed the earlier findings that the genes linked with $Y$ chromosome play an important role in gamete quality. Krzanowska and her coworkers used males from B10. BR and its congenic mutant strain B10. BR-Ydel with a large deletion in the long arm of the $Y$ chromosome. The cauda epididymidis of mutant males contained a higher than in normal males, percentage of spermatozoa with abnormal heads ( $88 \%$ v $31 \%)$. Sperm heads with flat acrosomes, present exclusively in the mutants (30\% of sperm population), were deficient in proteolytic enzymes. Most copulations of mutant males (11/18) were sterile in spite of the presence of spermatozoa in the uterus, but in the remaining copulations the fertilization rate was reasonably good (79\%). Low numbers of spermatozoa were recovered from the oviducts, and those with the most severely deformed heads were less frequent there than in the uterus. This clearly showed that a partial deletion of the $Y$ chromosome affected the efficiency of fertilization and sperm morphology (Styrna et al., 1991; Styrna and Krzanowska, 1995; Styrna et al., 2002).

Males of the B10. BR-Ydel mouse strain, with a deletion in the long arm of the $\mathrm{Y}$ chromosome, were backcrossed by Krzanowska, to $\mathrm{CBA} / \mathrm{Kw}$ females to introduce the Ydel chromosome to the genetic background of the CBA/Kw mice. The CBA-Ydel males (sixth backcross generation) had similar symptoms to those previously described for B10. BR-Ydel males but these symptoms were much less pronounced, indicating a favorable influence of the CBA/Kw genetic background. The CBA-Ydel males produced only $12 \%$ severely misshapen spermatozoa, and mating with B10. BR females gave $100 \%$ successful fertilization. Although nearly all sperm heads were abnormal (92\% v $6 \%$ in control males), most of the spermatozoa (76\%) had deformations only in the acrosomal part, that is, flat heads, which were not found in the control males. These abnormalities were analyzed in detail. As shown by differential staining, the acrosomes of the spermatozoa with flat heads were deformed; most of these acrosomes looked damaged, and often contained a vesicle, which stained like the acrosome but lacked the reaction for acrosomal proteinase. Electron microscopy of testis sections showed that the round spermatids had a distortion of the acrosomal vesicle and asymmetrical positioning of the acrosomal granule; in many elongating spermatids the proximal end had a flat or concave shape, and the acrosomes contained a translucent vesicle. This suggested that the genes that were missing in the Yq deletion had some important regulatory function in the course of spermiogenesis, which may explain the various sperm defects observed in Ydel males (Styrna et al., 2003). Using the computer- assisted system of semen analysis (CASA), we also showed that the Yq deletion affects some motility parameters of sperm (Grzmil et al., 2007).

In summary, the most important discoveries of Halina Krzanowska are:

1. Chromosome $Y$ affects the morphology of mice spermatozoa.

2. The uterotubal junction is in vivo a selection barrier for the morphologically abnormal spermatozoa, whereas in vitro this function is performed by the oocyte integuments.

3. Pubertal male mice produce a very high percentage of morphologically abnormal spermatozoa.

4. In mice chimaeras produced by combination of embryos from different inbred strains the character of spermatozoa is determined autonomously by germ cells.

5. The frequency of $X-Y$ dissociation at meiosis is increased in pubertal males and controlled by more than one gene active in germ cells.

6. The shape of the sperm head in mice correlates with the frequency of sperm abnormalities.

The current research in the Department of Genetics and Evolution is a continuation of Professor Krzanowska's work. We have obtained some precious and unique inbred recombinant strains, which we will use to map the genes responsible for gamete quality. The first results of this research are presented in the present volume (Golas, et al. 2008).

\section{References}

BARTKE, A. and KRZANOWSKA, H. (1972). Spermatogenesis in mouse strains with high and low abnormal spermatozoa. J. Heredity 63: 172-174.

BEATTY, R.A. (1970). The genetics of the mammalian gamete. Biol. Rev. 45: 73-119.

BORZEDOWSKA, B. (1963). Transition into a hereditary form of a thermal phenocopy in Drosophila melanogaster. Folia Biol. Krakow 11: 231-252.

BORZEDOWSKA, B. (1966). Penetration and expression of a hereditarily fixed thermal phenocopy as depending on sex in Drosophila melanogaster. Folia Biol. Krakow 14: 47-57.

BRADEN, A.W.H. (1958). Variation between strains of mice in phenomena associated with sperm penetration and fertilization. J. Genet. 56: 37.

BUDA, D. and KRZANOWSKA, H. (1978). Types of sperm head abnormalities in five inbred strains of mice (A, AKR, 129, C58, BALB). Zwierz. Lab. 15: 63-70. 
BURGOYNE, P.S. (1979). Evidence for an association between univalent $Y$ chromosomes and spermatocyte loss in XYY mice and men. Cytogenet. Cell Genet. 23: 84-89.

BURGOYNE, P.S. and BAKER, T.G. (1984). Meiotic pairing and gametogenic failure. In Controlling Events in Meiosis. Evans, C.W. and Dickinson, H.G. (eds) Company of Biologists, Cambridge 349-362.

GOLAS, A., DZIEZA, A., KUyNIARZ, K. and STYRNA, J. (2008). Mapping genes controlling four sperm quality parameters with the use of the recombinant inbred strains of mice. Int. J. Dev. Biol. 287-293.

GRZMIL, P., GOLAS A., MULLER, C. and STYRNA J. (2007). The influence of the deletion on the long arm of the $Y$ chromosome on sperm motility in mice. Theriogenology 67: 760-766.

IMAI, H.T., MATSUDA, Y., SHIROISHI, T. and MORIWAKI, K. (1981). High frequency of $X-Y$ chromosome dissociation in primary spermatocytes of $F 1$ hybrids bewteen Japanese wild mice (Mus musculus molossinus) and inbred laboratory mice. Cytogent. Cell Genet. 29: 166-175.

KRZANOWSKA, H. (1948). The influence of hypotonic solution on the endodermal cells from the area vitellina of the chick's blastoderm cultivated in vitro. Bull Acad Sci Cracov BII: 213-224.

KRZANOWSKA, H. (1949). The influence of hypertonic solution on the endodermal cells from the area vitellina of the chick'sblastoderm cultivated in vitro. Bull Acad Sci Cracov Bll: 73-93.

KRZANOWSKA, H. (1954). Investigation on the activity of mixed cock semen (In Polish) Folia Biol. Krakow 2: 169-184.

KRZANOWSKA, H. (1956). Seasonal variation in the quality of sperm in domestic fowl (In Polish) Roczn. Nauk Roln. 70: 301-315.

KRZANOWSKA, H. (1959). Early embryonal growth in inbred lines of Brown Leghorns and their crosses Poultry Sci. 38: 1446-1455.

KRZANOWSKA, H. (1962). Sperm quality and quantity in inbred lines of mice and their crosses. Acta Biol. Cracov Ser Zool. 5: 279-290.

KRZANOWSKA, H. (1966). Fertilization rate in mice after artificial insemination with epididymal or capacitated sperm from inbred and crossbred males. Folia Biol. Krakow 14: 171-175.

KRZANOWSKA, H. (1967). Analysis of fertility factors in inbred mice and F1 hybrids. Genet. Polon. 8: 231-234.

KRZANOWSKA, H. (1969). Factor responsible for spermatozoan abnormality located on the Y chromosome in mice. Genet. Res. Camb. 13: 17-24.

KRZANOWSKA, H. (1970). The relation between fertilization rate and penetration of eggs by supplemantary spermatozoa in different mouse strains and crosses. J. Reprod. Fertil. 22: 199-204.

KRZANOWSKA, H. (1972a). Rapidity of removal in vitro of the cumulus oophorus and zona pellucida in different strains of mice. J. Reprod. Fertil. 31: 7-14.

KRZANOWSKA, H. (1972b). Influence of the $Y$ chromosome on feritity in mice. Proc. Intern. Symp. The Genetics of the Spermatozoon (Eds R.A. Beatty and Gluecksohn - Waelsch): 370-386.

KRZANOWSKA, H. (1974). The passage of abnormal spermatozoa through the uterotubal junction of the mouse. J. Reprod. Fertil. 38: 81-90.

KRZANOWSKA, H. (1976). Inheritance of sperm-head abnormality types in micethe role of the $Y$ chromosome. Genet. Res. Camb. 28: 189-198.

KRZANOWSKA, H. (1978). Inbred mice in studies on genetic factors of fertility Zwierz. Lab. 15: 81-84.

KRZANOWSKA, H (1981). Sperm head abnormalities in relation to the age and strain of mice. J. Reprod. Fertil. 62: 385- 392.

KRZANOWSKA, H. (1986). Interstrain competition amongst mouse spermatozoa inseminated in various proportions, as affected by the genotype of the $Y$ chromosome. J. Reprod. Fertil. 77: 265-270.

KRZANOWSKA, H. (1989). X-Y chromosome dissociation in mouse strains differing in efficiency of spermatogenesis: Elevated frequency of univalents in pubertal males. Gamete Res. 23: 357-365.

KRZANOWSKA, H. and LORENC, E. (1983). Influence of egg investments on in vitro penetration of mouse eggs by misshapen spermatozoa. J. Reprod. Fertil. 68: 57-62

KRZANOWSKA, H. and MUSIALEK, B. (1971). Efficiency of matings between a low fertile inbred mouse strain and an outbred strain. Genet. Polon. 12: 561-568.

KRZANOWSKA, H., WABIK-SLIZ, B. and RAFINSKI J. (1991). Phenotype and fertilizing capacity of spermatozoa of chimaeric mice produced from two strains that differ in sperm quality. J. Reprod. Fertil. 91: 667-676.

POLANSKI, Z. and KRZANOWSKA, H. (1991). Similar level of aneuploidy in mouse spermatozoa from two inbred strains differing in the frequency of $X-Y$ dissociation at meiosis. Genet. Polon. 32: 43-49.

STYRNA, J., BILINSKA, B. and KRZANOWSKA, H. (2002). The effect of a partial $Y$ chromosome deletion in B10.BR-Ydel mice on testis morphology, sperm quantity and efficiency of fertilization. Reprod. Fertil. Dev. 14: 101-108.

STYRNA, J., IMAI, H.T. and MORIWAKI, K. (1991). An increased level of sperm abnormalities in mice with a partial deletion of the $\mathrm{Y}$ chromosome. Genet. Res. 57: 195-199.

STYRNA, J., KILARSKI, W. and KRZANOWSKA, H. (2003). Influence of the CBA genetic background on sperm morphology and fertilization efficiency in mice with a partial Y chromosome deletion. Reproduction 126: 579-588.

STYRNA, J. and KRZANOWSKA, H. (1995). Sperm select penetration test reveals differences in sperm quality in strains with different $Y$ chromosome genotype in mice. Arch. Androl. 35: 111-118. 


\section{Related, previously published Int. J. Dev. Biol. articles}

See our recent Special Issue Developmental Biology in Poland edited by Kloc, Maleszewski and Tarkowski at: http://www.ijdb.ehu.es/web/contents. php?vol=52\&issue=2-3

See our Special Issue Mammalian Reproduction \& Development in honor of Anne McLaren and edited by Brigid Hogan at:http://www.ijdb.ehu.es/web/contents.php?vol=45\&issue=3

Dynamic distribution of the replacement histone variant $\mathrm{H} 3.3$ in the mouse oocyte and preimplantation embryos

Maria-Elena Torres-Padilla, Andrew J. Bannister, Paul J. Hurd, Tony Kouzarides and Magdalena Zernicka-Goetz

Int. J. Dev. Biol. (2006) 50: 455-461

The making of gametes in higher plants

Leonor C. Boavida, Jörg D. Becker and José A. Feijó

Int. J. Dev. Biol. (2005) 49: 595-614

Distinct mechanisms underlie sperm-induced and proteaseinduced oolemma block to sperm penetration.

Sebastian Komorowski, Katarzyna Szczepanska and Marek Maleszewski

Int. J. Dev. Biol. (2003) 47: 65-69

Reproductive ageing and the menopause.

C A Finn

Int. J. Dev. Biol. (2001) 45: 613-617

Germ cell biology--from generation to generation.

P J Donovan, M P De Miguel, M P Hirano, M S Parsons and A J Lincoln

Int. J. Dev. Biol. (2001) 45: 523-531

Sperm-egg interaction at fertilization: glycans as recognition signals.

F Rosati, A Capone, C D Giovampaola, C Brettoni and R Focarelli Int. J. Dev. Biol. (2000) 44: 609-618

The role of stem cell factor and of alternative c-kit gene products in the establishment, maintenance and function of germ cells. C Sette, S Dolci, R Geremia and P Rossi Int. J. Dev. Biol. (2000) 44: 599-608

Sperm quality in spontaneous unilateral abdominal cryptorchid boars.

E Pinart, R Camps, M D Briz and S Bonet

Int. J. Dev. Biol. (1996) 40: S225-S226
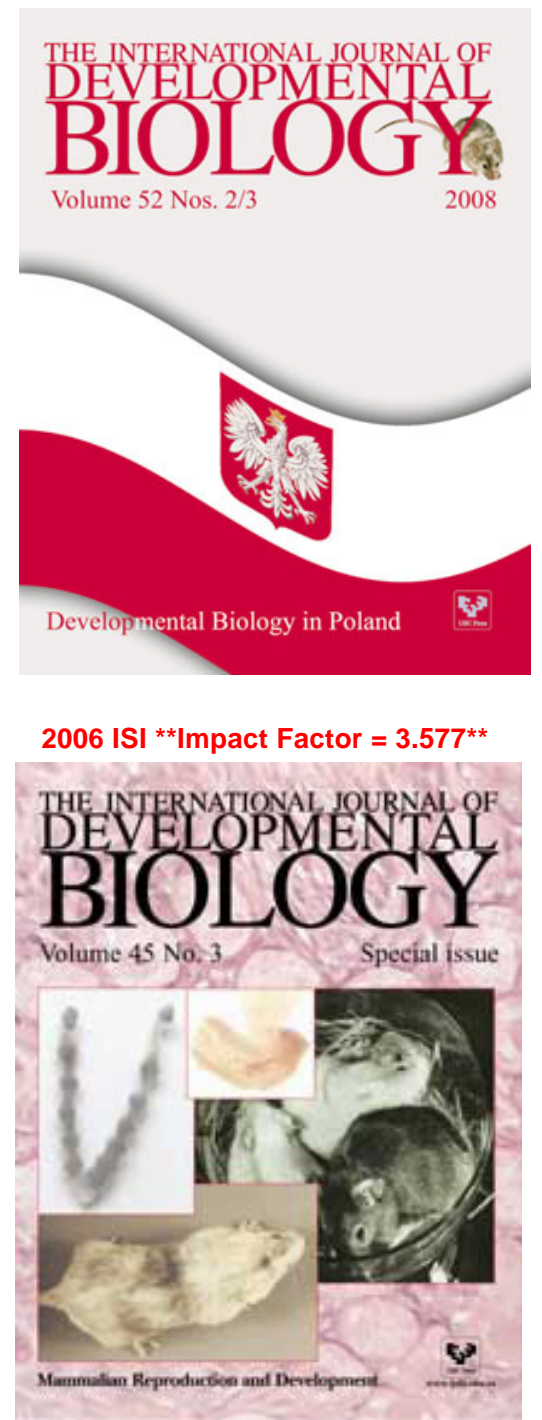